\title{
The Changing Perspectives of Chinese Law: Socialist Rule of Law, Emerging Case Law and the Belt and Road Initiative
}

\author{
$L u X u$ \\ Lancaster University, United Kingdom \\ lu.xu@lancaster.ac.uk
}

\begin{abstract}
This article identifies and clarifies some of the miscommunication between Chinese and English in the discussion of rule of law or rule by law. "Rule by law" is not a concept readily understandable by a Chinese audience because there is no acceptable translation or equivalent in Chinese. At the same time, the historical and contextual significance of the different denotations of "rule of law" in Chinese is often overlooked in an English-speaking environment. Meanwhile, the abstraction in critical examination of Chinese law often masks significant changes taking place in China's construction of a "socialist rule of law with Chinese characteristics", such as the emergence of a system of case law. The different components and aspects of such a system, ranging from the guidance cases system published by the Supreme People's Court, to the largest database of judicial decisions in the world, and the newly established China International Commercial Court under the Belt and Road Initiative could fundamentally alter and structure, nature and principles of Chinese law as we know it.
\end{abstract}

\section{Keywords}

Chinese law - rule of law - case law - China International Commercial Court 
It is evident that the rise of China, underlined by its economic power and growth, now has profound impact on the world across a wide realm such as culture, politics and technology. Chinese law, however, has so far been a rather self-contained area with minimal external influence in comparison to other institutions of general importance in modern society. On the practical side, Chinese law does not seem to concern persons and organizations outside of China. Within academia, many substantive scholarly studies of Chinese law written in English often focus on what China can learn from the more established Western legal systems, especially in specific branches of the law, say intellectual property or environmental protection. To put it more bluntly, the question being asked is often how Chinese law is different from the law of the US or European countries and how Chinese law can be improved based on such comparative knowledge. While such an approach is undoubtedly valuable, it tends to leave a void in the understanding of the more systemic and fundamental changes that happen in Chinese law among the audience outside of China. In other words, what is often not being scrutinized is how Chinese law is different and changing fast, and how this could alter our understanding of Chinese law and its influence both in and out of China.

This article seeks to make its contribution towards filling that gap through critical examination of a series of ongoing changes in the Chinese legal system that have not received the attention their importance would warrant so far. It will start by identifying the typical miscommunication between English and Chinese on the issue of the rule of law or rule by law, including the contextual importance of the seemingly cosmetic amendment of the Chinese constitution on the socialist rule of law. It will then focus on the gradual emergence of a system of the use of cases against the background of a Civil Law jurisdiction, by examining the different perspectives of the system of guiding cases from the Supreme People's Court, the China Judgement Online Database, and the potential impact of the establishment of the China International Commercial Court under the Belt and Road Initiative.

Since 1999, the Constitution of China states that "[ $t$ ]he People's Republic of China governs the country according to law and makes it a socialist country 
under rule of law". ${ }^{1}$ The criticism that China is not a rule of law country has never subsided. In March 2018, the National People's Congress adopted the first set of constitutional amendment in more than a decade. Among other changes that caught international attention, most notably the removal of the twoterm limit for the position of the President, the statement in the Preamble on "improving the socialist legal system" was rewritten as "improving the socialist rule of law". It seems fair to suggest that many commentators outside of China, especially those not familiar with the subtlety of the Chinese language in this context, remain rather unsure of this change. Is this something of significance in the continuing reform of the legal system in China, or is it just another lipservice in China's propaganda to present itself as a rule of law country?

Eminent legal scholars have pointed to the different connotations of the rule of law and the potential for "promiscuous use". ${ }^{2}$ Raz explains that the rule of law literally means the rule of the law, and in its broadest sense that people should obey the law and be ruled by it. At the same time, the narrower sense of the phrase in political and legal theory comes to be read as that the government shall be ruled by the law and subject to it. ${ }^{3}$ Despite a reversed sense of broadness or narrowness, the essence of the different theories of the rule of law is largely echoed in Peerenboom's "thin" and "thick" version of the rule of law with a particular focus in the context of China. ${ }^{4}$ In a similar vein, Orts observes that a number of legal theorists have distinguished a prescriptive, normative and political view of the relationship between law and the state from a descriptive, positive and instrumental view of the two. The latter is referred to as rule by law. ${ }^{5}$

The "rule by law" label certainly has been used frequently enough in this area for it to be seen as an effective shorthand to criticize if not mock the Chinese system. The media would readily run statements about how China is a rule by law country and not a rule of law country, presumably on the assumption that the general public is well versed in the differences. When reporting

1 Constitution of the People's Republic of China, Article 5. Translation of the 2004 version (no change to Article 5) by the National People's Congress is available at $<\mathrm{http} / /$ www.npc .gov.cn/englishnpc/Constitution/node_2825.htm> accessed 1 January 2019.

2 Joseph Raz, The Authority of Law (2nd ed., 2009, Oxford University Press) 211.

3 Raz, 212.

4 Randall Peerenboom, China's Long March Towards the Rule of Law (2002, Cambridge University Press), 3 .

5 Eric W. Orts, "The Rule of Law in China" (2001) 34 Vanderbilt Journal of Transnational Law 43, 93-4. 
on the aforementioned Chinese constitutional amendment in 2018, the Law Library of Congress of the United States saw fit to include the only comment in its factual news update on the Chinese constitution text of "improve the socialist rule of law", as tersely as "which is effectively rule by law, one could argue". ${ }^{6}$ Even some academic pieces would throw in such a twist as a self-evident conclusion, without explaining the notable scope or variants of "rule of law" that leading scholars have been discussing over the past decades. ${ }^{7}$

Whatever the critics sought to achieve with such clever use of terminology, they seem oblivious to the important fact that "rule by law" has no capable translation into the Chinese language. Consequently, for the vast majority of Chinese who do not command the level of English that would enable them to read about law and politics in a foreign language, these criticisms from the outside are often incomprehensible, thus seemingly unreasonable, once translated into Chinese.

In the absence of a widely understandable expression in Chinese, some have tried to translate "rule by law" as equivalent to "以法治国 yı fa zhi guo" (govern the nation by law). There are a number of reasons why this would be rather unhelpful in explaining the concept to the Chinese audience. The phrase was first used by Legalist politicians and philosophers such as Guan Zhong (725-645 BC) and Han Fei $(279-233$ BC $),{ }^{8}$ but hardly found its way into the common parlance for the next two thousand years. This largely forgotten historic phrase may struggle to fit into a role of explaining contemporary thinking with all the Legalistic baggage attached to it. At the same time, “y̌́fa zhi guo" is a close homophone to “依法治国yı̃fa zhiguo" (govern the country according to law), which is the core value enshrined in the Constitution, discussed below. ${ }^{9}$ The possible confusion inherent in such subtle differences would hardly help to clarify the already complex subject matter. Furthermore, the phrase, being unused in the past, has never carried any approbative or pejorative sense to it, unlike the "rule by law" label in English with its dedicated use in criticism. So any criticism that "China is doing y̌̌ fa zhi guo!" would still leave the Chinese audience bewildered as before.

6 Laney Zhang, "China: 2018 Constitutional Amendment Adopted" (Library of Congress, 18 May 2018) <http://www.loc.gov/law/foreign-news/article/china-2018-constitutional -amendment-adopted/> accessed 1 January 2019.

7 E.g. Chien-yuan Tseng, "Human Rights Are Human Rights: Asian Values, Chinese Characteristics and Universal Values" (2017) 3(2) Contemporary Chinese Political Economy and Strategic Relations 989, 997.

8 《管子. 明法》: “以法治国则举错而已”; 《韩非子. 有度》: “故以法治国举措而已矣”.

9 Constitution of the People's Republic of China, Article 5. 
Nevertheless, there have been attempts of even worse translation, by equating the notion of “法制 fa zhi" (legal system) to "rule by law". This fa zhi (legal system) is a complete homophone to “法治 fa zhi" (rule of law) and the existence of two different $f a z h i$ is certainly an easy cause for confusion for non-Chinese speakers in this area. ${ }^{10}$ For example, when Keith observed in 1994 that "during the Chinese legal reform of the 1980 , Western commentary ... routinely presumed that any Chinese reference to 'fazhi' connoted 'rule by law' as opposed to 'rule of law'", it is unclear which $f a$ zhi the author was referring to. ${ }^{11}$ Leaving aside the confusion of identical pronunciation, $f a$ zhi (legal system) in Chinese is still a neutral, if not modestly approbative, term without any derogatory connotation. Chinese legal scholars routinely write about not just the fa zhi (legal system) of China but the fa zhi (legal system) of other countries. For example, there is no indication that when writing about the fa zhi (legal system) of the United Kingdom, any Chinese author was in fact commenting on the rule-bylaw status of the country. ${ }^{12}$

More importantly, the idea of besmirching the connotation of fa zhi (legal system) with that of rule by law in English completely disregard the content and history behind the two "fa zhi", which have played pivotal roles in the development of law in modern China. In the wake of the catastrophic Cultural Revolution, fa zhi (rule of law) was actually the earlier of the two to gain prominence among political and academic discourse at the beginning of the Reform and Opening Up in the late 1970s and early 1980s. However, there is no evidence to suggest that fa zhi (rule of law) discussed in China at that time had any link to the concept or phrase of "rule of law" in English. Instead, fa zhi (rule of law) was used in the sense of "governing by law" as opposed to ren zhi (governing by men). ${ }^{13}$ Li Buyun and Wang Liming, both leading scholars at the time and for years to come in this area, highlighting the translated expression "to the end it may be a government of laws and not of men" from the Constitution of Massachusetts, state that "a government of laws and not of men" is definitely fa zhi (rule of law). ${ }^{14}$ Despite what would now seem like an obvious choice, it took the conjoined efforts of many to finally deny the legitimacy of any form

10 Debora Cao, Chinese Law: A Language Perspective (2004, 2016 reprint by Routledge) 42. Professor Cao's helpful approach to label every $f a$ zhi clearly is gratefully adopted in this article.

11 Ronald Keith, China's Struggle for the Rule of Law (1994, Palgrave Macmillan) 1.

12 刘振宇, “英国法制建设的几点启示与借鉴” (2002/02) Contemporary Law Review 105.

13 王礼明, “试论人治与法治” (1979/11) Academic Monthly 22.

14 李步云 王礼明, “人治和法治能互相结合吗?” (1980/2) Chinese Journal of Law 40, 45. 
of governing by men and to reach the eventual consensus that ren zhi and fa zhi (rule of law) are mutually repugnant and cannot be adopted as some form of combination despite early suggestions.${ }^{15} \mathrm{Fa} z h i$ (rule of law) prevailed in the end, but not in the sense that the term is used in English at all. This connotation of the Chinese word fa zhi (rule of law) is often overlooked by discussions in English, but it continues to be used in contemporary Chinese literature without any concern. ${ }^{16}$

In the late 1980 s and early 1990s, the rise of $f a z h i$ (rule of law) was abruptly interrupted by domestic and international events and the ensuing changes in the political atmosphere. $\mathrm{Fa}$ zhi (rule of law) largely disappeared from the vocabulary of official discourse. Academics, in search for a replacement, opted to use the less nuanced term of $f a$ zhi (legal system) instead. ${ }^{17}$ When the Central Committee of the Communist Party of China issued its major "Decisions" on the socialist market economy in 1993, which is often regarded as the historic moment to kick-start the stalling Chinese economy, $f a$ zhi (legal system) was mentioned nine times while $f a$ zhi (rule of law) was not used at all. A lot of work behind the scene was done in order for $f a z h i$ (rule of law) to become admissible again. To that extent, fa zhi (rule of law) did remarkably well in the next six years, as did the Chinese economy, to be formally codified into the Constitution in the 1999 Amendment. Nevertheless, the usage of fa zhi (legal system) still outnumbered $f a$ zhi (rule of law) in the Constitution by three to one. ${ }^{18}$ The status of $f a z h i$ (rule of law) also had to contend with novel initiatives such as de zhi (rule of virtue), with leading scholars meticulously demarcating the boundaries between law and morality. ${ }^{19}$ It took almost two decades for the 2018 constitutional amendment to replace one of the three references to $f a z h i$ (legal system) with fa zhi (rule of law), so that the terms are now on numerical parity. Although commentators outside of China could easily dismiss the significance of such a seemingly cosmetic change, for many Chinese, including scholars who dedicated their careers advocating the importance of $f a z h i$ (rule

15 何华辉 马克昌 张泉林, “实行法治就要摒弃人治” (1980/4) Chinese Journal of Law 62.

16 E.g. 郭晔 张文显, “新时代首次修宪的法理基础” (2019/1) Law Review 1, 5 .

17 谢海定, “中国法治经济建设的逻辑” (2017/6) Chinese Journal of Law 21, 22.

18 Constitution of the People's Republic of China (as amended in 1999), Preamble, Article 5 and Article 24. Professor Cao's explanation that " $f a z h i$ (rule of law) is the phrase used in the Constitution" seems slightly misleading in this context, Cao, Ibid.

19 张骐, “法治的魂与形：兼谈法治与德治的区别与关联” (2018/2) ECPUL Journal 43, $5^{8-9}$. 
TABLE 1 Meaning and sense of relevant terminology in English and Chinese

\begin{tabular}{|c|c|c|c|c|}
\hline Chinese & Sense & Meaning & English & Sense \\
\hline $\begin{array}{l}\text { 法制 } \\
\text { (fazhi } \\
\text { “legal system”) }\end{array}$ & neutral & legal system & legal system & neutral \\
\hline $\begin{array}{l}\text { 法治 } \\
\text { (fa zhi } \\
\text { "rule of law") }\end{array}$ & approbative & $\begin{array}{l}\text { the political view or } \\
\text { ideal where the people } \\
\text { and (more importantly) } \\
\text { the government are subject } \\
\text { to and ruled by the law }\end{array}$ & rule of law & approbative \\
\hline $\begin{array}{l}\text { 法治 } \\
\text { (fa zhi } \\
\text { “rule of law") }\end{array}$ & approbative & $\begin{array}{l}\text { governing by law, as } \\
\text { opposed to governing } \\
\text { by men }\end{array}$ & $\begin{array}{l}\text { government of laws } \\
\text { (and not of men) }\end{array}$ & neutral \\
\hline $\begin{array}{l}\text { 依法治国 } \\
\text { (yīfa zhi } \\
\text { guo })\end{array}$ & approbative & ??? & $\begin{array}{l}\text { govern the country } \\
\text { according to law }\end{array}$ & neutral \\
\hline NONE & NONE & $\begin{array}{l}\text { the positivism concept of } \\
\text { governing by established } \\
\text { law, often associated with } \\
\text { authoritarian regimes }\end{array}$ & rule by law & pejorative \\
\hline
\end{tabular}

of law), the subtle change is at least a continued commitment to the progress China has undoubtedly made in improving its legal system and the rule of law over the past decades as well as the direction of travel for years to come.

Table 1 should hopefully summarize and clarify the discussion so far. There is, however, a central issue in this context which has only been mentioned in passing, namely the exact meaning of "yi fa zhi guo" (govern the country according to law). For a term that has been in the Constitution for twenty years and frequently emphasized by the Chinese leader President Xi Jinping, it is nevertheless still challenging to convey its exact connotation into the English discussion. The Chinese government and the Communist Party tend to use $y \bar{\imath} f a z h i g u o$ as a close synonym and possibly an elaboration of $f a z h i$ (rule of law). After all, fa zhi (rule of law) are the two characters literally at the centre of $y \bar{l} f a z h i$ guo. Furthermore, the literal meaning of $y \bar{l} f a$ zhi guo comes very close to the familiar connotation of $f a z h i$ (rule of law) in Chinese as "governing by law" as the opposite of "governing by men".

Nonetheless, a significant linguistic difference exists between the Chinese term "yi fa zhi guo" and the English term "rule of law". Raz's statement, cited above, is the clearest in explaining the literal meaning in English, that "the 
rule of law ... is the rule of the law". ${ }^{20}$ The literal expression makes it explicit that it is the law that rules, not any other entity. As to whether the law rules over the people, or the government, or both, the expression itself is silent. In English, the subject (the law) of the ruling is clear while the object is not. In the Chinese expression yi fa zhi guo, however, the law is clearly not the ruling entity. Someone or something else rules the country according to law. The expression is silent on who exactly rules. In contrast to the English translation, the Chinese expression stipulates the object (the country) but not the subject, while " $y \bar{\imath} f a$ " (according to law) only functions as the adverbial. The Chinese Constitution offers little help here by stating that "the People's Republic of China governs the country according to law". ${ }^{21}$ That, with respect, is a mere tautology without identifying who or what governs the People's Republic.

Furthermore, the ambiguity of the term is compounded by the scope of the expression $f a$ or fa lü for "law" in Chinese. As Chinese scholars have noted, Chinese and English seem to be the two major languages that do not inherently distinguish between law as an abstract concept of some universality and law as the actual collective of rules enacted by the State, unlike Latin (ius and lex), Spanish (derecho and ley), Italian (dritto and legge), French (droit and loi), German (Recht and Gesetz) or Turkish (hukuk and kanun). ${ }^{22}$ It remains to be seen whether whoever "governs China according to law" governs it only according to the law as enacted by the National People's Congress, or some abstract sense of law of more universality and values that is not limited in such a formalistic way.

Miscommunication between Chinese and English

All such linguistic and cultural differences, as well as quite often poor translations done without appreciating the implications of the admittedly confusing terminology, often lead to the message being lost in communication between China and the outside. When someone says in English "China is not a rule-oflaw country but a rule-by-law country", it is unlikely for the person to realize that the second half of this simple statement would be nearly impossible to translate into Chinese. Hence for the Chinese audience, only the first half of

\footnotetext{
20 Raz, 212.

21 Constitution of the People's Republic of China, Article 5 .

22 张骐 等, 中国司法先例与案例指导制度研究 < Study on Chinese Judicial Precedents and the System of Case Guiding > (2016, Peking University Press) 8.
} 
this message gets through, effectively that China is not a country with fa zhi (rule of law). This then in turn produces a response from the Chinese side that China is indeed a rule-of-law country. The Chinese speaker, be it a diplomat or a scholar, could well have been thinking about the prominent distinction between fa zhi (rule of law) and ren zhi (governing by men) that the Chinese collective understanding has embraced for forty years. The Chinese have always been informed that governing the country according to law is definitely the rule of law. Thus, it is completely understandable that many would firmly believe that China has some form of rule of law. "The rule of law is a political ideal which a legal system may lack or possess to a greater or lesser degree."23 Despite shortcomings in various aspects of the law, which many Chinese would readily admit even criticize, they would struggle to subscribe to the accusation that China, having travelled so far from the era of ren zhi, still does not have at least some degree of $f a z h i$ (rule of law).

There is no easy solution to address such prevalent miscommunication. On the one hand, China would need to develop the collective understanding of the concept of rule of law to that beyond the traditional dichotomy of governing by law or governing by men. As Peerenboom points out, "China lacks the soft power to challenge the global dominance of the liberal democratic conception of rule of law" and "critics at home and abroad will, fairly or unfairly, continue to assess reforms and measure China against the standard of liberal democratic rule of law". ${ }^{24}$

On the other hand, the rule of law should not be used by critics of China as a blanket catch-all instrument that denotes everything negative about China or the Chinese government. "It is also to be insisted that the rule of law is just one of the virtues which a legal system may possess ... It is not to be confused with democracy, justice, equality ... human rights of any kind ..."25 In scholarly writings in particular, the irresponsible branding of issues as rule-of-law related does disservice not only to the efforts to improve the law in China or elsewhere but to the integrity and credibility of the rule of law concept as a whole. For example, in a recent article assessing the impact of trade with Mainland China on the rule of law in Hong Kong and Taiwan, a commentator categorized numerous issues in relation to "freedom of expression, freedom of speech and freedom of thought and conscience" as evidence of "erosion of

\footnotetext{
23 Raz, 211.

24 Randall Peerenboom, "Fly High the Banner of Socialist Rule of Law with Chinese Characteristics!" (2015) Hague Journal of Rule of Law 49, 72-3.

25

Raz, 211.
} 
the rule of law". ${ }^{26}$ Inexplicably, the case then used as evidence of such erosion was where a Hong Kong court ruled that freedom of expression would not be a defence in criminal desecration of the national or regional flag. ${ }^{27}$ With the greatest respect, do all countries with well-established rule-of-law, such as France, ${ }^{28}$ Germany, ${ }^{29}$ New Zealand ${ }^{30}$ amongst others, allow desecration of their national flags as freedom of expression? Is it not a basic tenet of the rule of law that the promulgated law of a jurisdiction, not to mention criminal law, should be obeyed by its citizens?

It suffices to say that the potential gap in understanding and communication between Chinese speakers and English speakers in this regard would continue to exist. Instead of generalizing all political and law-related issues as some examination of rule of law in China, it may be more helpful to examine some important development in the fundamental mechanics of the Chinese legal system with more profound impact on the law in China.

Neither the publication of decided cases by the Supreme Court nor the attention paid to such practice is new in the study of Chinese law over the past decades. ${ }^{31}$ There was, for example, reflection on the scrutiny from "Western scholars" in the early 199os on the publication of the Gazette of the Supreme People's Court of the People's Republic of China. ${ }^{32}$ More recently, the attention tends to focus on the new system of "guiding cases" published by the Supreme People's Court, which was first announced in 2010 and commenced in 2011. ${ }^{33}$

26 Chien Huei Wu, "Dance with the Dragon: Close Economic Integration with China and Deteriorating Democracy and Rule of Law in Taiwan and Hong Kong?" (2015) Hong Kong Law Journal 275, 276-7.

$27 \quad H K S A R v$ Ng Kung Siu (1999) 2 H KCFAR 442.

28 Code pénal, Article 433-5-1.

29 Strafgesetzbuches, s.9oa.

3o Flags, Emblems, and Names Protection Act 1981, s.11.

31 It is noted that the Supreme People's Procuratorate has also been publish guiding cases. However, given their nature and the limited scope within criminal prosecution, it is left out of the current discussion on the more general aspects of the use of cases in Chinese law.

32 Nanping Liu, 'Legal Precedents' with Chinese Characteristics: Published Cases in the Gazette of the Supreme People's Court" (1991) 5Journal of Chinese Law 107, 107.

33 For a helpful account of the history and structure of the system of guiding cases, see Anonymous, "Chinese Common Law? Guiding Cases and Judicial Reform" (2016) 129 Harvard Law Review 2213. 
As of the end of 2018, there are 106 guiding cases covering many areas of civil, criminal and administrative law as well as enforcement of judgments. In October 2018, the Standing Committee of the National People's Congress adopted amendments to the Organic Law of the People's Courts of the People's Republic of China, adding the provision that "the Supreme People's Court may publish guiding cases". ${ }^{34}$

Some commentators seem to allude to a link between the publication of guiding cases in China and the Common Law tradition. ${ }^{35}$ Although such a label makes interesting titles, it is rather premature to find any substantive connection between these new guiding cases and the common law. As others have noted, the Chinese practice seems to be more analogous to the use of cases in Civil Law jurisdictions rather than in the Common Law tradition. ${ }^{36}$ In this regard, Chinese scholars have typically examined German law as the prime example of the use of cases in a Civil Law country, with notable efforts to explain and analyse concepts such as "Präjudiz" and "Richterrecht". 37 Nevertheless, perhaps the more prevailing view among Chinese scholar is that the Chinese system has notable "Chinese characteristics" not seen in other Common Law or Civil Law countries, even if there are many shared functions and reasons for using cases in any legal system. ${ }^{38}$ Some of these Chinese characteristics are certainly significant enough to render the choice between Civil Law or Common Law as the better analogy almost a non-question.

In the first place, the Supreme People's Court select guiding cases from all levels of courts in China, including more than 3,00o basic people's court at the bottom of the court hierarchy. Among the first 92 guiding cases published by the end of 2017, 18 of these were decisions by the basic people's courts. ${ }^{39}$

34 Organic Law of the People's Courts of the People's Republic of China (as amended on 26 October 2018), Article 18.

35 E.g. Jocelyn Limmer, "China's New Common Law: Using China's Guiding Cases to Understand How to Do Business in the People's Republic of China” (2013) 21 Williamette Journal of International Law \& Dispute Resolution 96; Danny Friedmann, "IP in China: Moving closer to the common law system for the sake of uniformity" (2017) 12 Journal of Intellectual Property Law \& Practice 621.

36 Anonymous, "Chinese Common Law? Guiding Cases and Judicial Reform" (2016) 129 Harvard Law Review 2213, 2232.

37 E.g. 张骐 等, 中国司法先例与案例指导制度研究 <Study on Chinese Judicial Precedents and the System of Case Guiding> (2016, Peking University Press) 104; 陈兴良 (ed.) 中国案例指导制度研究 <Chinese System of Directive Cases> (2014, Peking University Press) 712 .

38 E.g. 张志铭, “司法判例制度构建的法理基础” (2013) 7 Tsinghua Law Journal 91, 92.

39 北大法律信息网，“最高人民法院指导性案例 2017 年度司法应用报告” $<\mathrm{http}: / /$ weekly.pkulaw.cn/Admin/Content/Static/374cc337-gede-4377-86o6-bd2313f9f78.html> accessed 1 January 2019 . 
In other words, these are first instance decisions not having been subject to any appeal, yet are then elevated to the status of guiding cases of national importance soon after. From the Common Law perspective, such as in England and Wales, first instance decisions have little binding force on any court of equal jurisdiction. ${ }^{40}$ From the Civil Law perspective, such as in France, any legal precedent only becomes a de facto (but not de jure) authority until "it is definitely fixed by the repetition of precedents which are in agreement on a single point". ${ }^{41}$ Chinese guiding cases are constrained by neither the necessary appellate status of the court making the decision nor the repetition of other courts in approval. It is a matter of being approved by the Supreme People's Court independent of any litigation after the original decision.

At the same time, guiding cases are subject to edit by the Supreme People's Court not only for the highlighting of the legal principles involved but also possible rewriting of both the text of the court reasoning and some factual aspects of the original litigation. ${ }^{42}$ There is no indication that the changes made by the Supreme People's Court have created any material difference from the original court decision. Often the edits emphasize or make it explicit what the original decision was inferring to. Still, guiding cases are edited as condensed models or good examples, instead of the full decision announced by the court originally. Volume-wise, a typical guiding case would fit a couple of A4 pages while the original decision handed down by the court nowadays could easily span 15 or 20 pages.

It may thus be observed that the system of guiding cases is essentially an instrument of the Supreme People's Court that would convey accelerated and concentrated judicial opinions from the highest court in the country to all the courts below. It does not wait for the ideal case to be thoroughly examined on appeal and it could, modestly at least, modify a usable case to suit the need of providing guidance. Unlike Common Law precedents, guiding cases are not established by the appellate courts in their judicial decision-making due to their elevated position on the hierarchy of courts. And unlike Civil Law precedents, guiding cases are not dependent on any consensus built up in a series of decisions by different judges.

The pressing question following such an understanding is what difference the new system of guiding cases would make to the operation and

$40 \quad$ Rupert Cross \& J.W. Harris, Precedent in English Law (1991, 4th ed., Clarendon Press) 122.

41 Edouard Lambert \& Max J. Wasserman, "The Case Method in Canada and the Possibilities of its Adaptation to the Civil Law" (1929) 39 Yale Law Journal 1, 15 .

42 For an example of the extent of editing, see Stanford Law School China Guiding Cases Project, "Guiding Case No. 1" <https://cgc.law.stanford.edu/guiding-cases/guiding-case-1/> accessed 1 January 2019. 
development of Chinese law. From the start, guiding cases are different from those hundreds of cases selected and published by the Supreme People's Court since the 1980 s in that they are given a formal role in the judicial decisionmaking process. The Supreme People's Court first promulgated Provisions in 2010 and then Detailed Rules in 2015 in relation to guiding cases, both stating that courts at all levels "should" (ying dang 应当) "refer to" (can zhao 参照) guiding cases when adjudicating similar cases. ${ }^{43}$ Although for laypersons and those not familiar with the subtlety of legislative language in China the word "should" may appear ambiguous, ${ }^{44}$ it essentially reads as "must" (bixu 必须) and is the preferred choice of wording for imposing obligations in legislation. ${ }^{45}$ The Detailed Rules also state that the court should cite guiding cases as part of the "reasoning" of any decision, but not the "basis" for making such a decision. ${ }^{46}$ This largely conforms with the prevalent academic assessment that guiding cases now have de facto binding force but are not de jure law. ${ }^{47}$ This rather intriguing position is perhaps a reflection of the long-term unease the judiciary have harboured of being accused of making law in a system which is clearly Civil Law based without any Common Law heritage, especially when questioned in relation to legislative functions in competition with the National People's Congress. ${ }^{48}$ In this regard, the recognition of the ongoing publication of guiding cases by the legislator in the aforementioned 2018 amendments to the Organic Law of the People's Court is highly significant, as the first ever mention of the use of cases in primary legislation. Interestingly, the legislation is completely silent as to what legal effect, if any, guiding cases would have. In other words, it is a nod by the National People's Congress to the Supreme People's Court to carry on with what it is doing without clarifying what the practice means.

43 Provisions of the Supreme People's Court Concerning Work on Case Guidance (最高人 民法院关于案例指导工作的规定) (26 November 2010), Article 7; Detailed Rules for the Implementation of the Provisions of the Supreme People's Court Concerning Work on Case Guidance (最高人民法院关于案例指导工作的规定实施细则) (13 May 2015), Article 9.

44 Anonymous, "Chinese Common Law? Guiding Cases and Judicial Reform" (2016) 129 Harvard Law Review 2213, 2223 fn 87.

45 Legislative Affairs Sub-Committee of the Standing Committee of the National People's Congress, "Technical Standard for Legislation (Trial Implementation) (Part One)" (《立法技术规范（试行）（一）》法工委发 [2009] 62 号), Article 14.

46 Detailed Rules for the Implementation of the Provisions of the Supreme People's Court Concerning Work on Case Guidance, Article 10.

47 泮伟江, “论指导性案例的效力” (2016) 10 Tsinghua University Law Journal 20, 21.

48 雷否, “指导性案例法源地位再反思” (2015) China Legal Science 272, 286. 
And it seems that the Supreme People's Court has been emboldened by such gesture and would carry on developing the institution of guiding cases. December 2018 saw 10 guiding cases published, making this the most productive month so far since these started in 2012. Nevertheless, the continuing growth of guiding cases may well force Chinese law to come to terms with a crucial choice sooner rather than later, namely what role do other cases play in the legal system. One possibility is that an established structure of guiding cases may pave the way for more accomplished use of cases in Chinese law as judges and practitioners become more familiar with the methods and philosophy. The lead and effort by the Supreme People's Court in this regard may well be instrumental in educating a system which have often shown reluctance towards case law as a product of the Common Law tradition. Yet another possibility, often overlooked, is that guiding cases would take over and become the only cases the court is allowed to consider, thus significantly limiting rather than enhancing the use of cases in Chinese law.

Despite the lack of de jure recognition and de facto binding effect, cases have been studied and used in practice before and after the inception of the current system of guiding cases ${ }^{49} \mathrm{After}$ all, treating like cases alike is a well understood basic principle in China as much as it is elsewhere. ${ }^{50}$ Nevertheless, the ascendency of guiding cases have now led to the questioning of the use of any other case in the court recently.

In many litigations, the fact that a court had taken in to consideration decided cases which were not guiding cases came under fire by parties on appeal or when applying for a retrial..$^{51}$ The logic behind such an argument is understandable, though arguably erroneous, especially when assessed in the context that parties would be clutching at straws when trying to challenge a decision. Given the special status of guiding cases, some would expectedly argue any case that does not qualify as the guiding case must be treated less

\footnotetext{
49 周道变. “中国案例制度的历史发展” (2004) Journal of Law Application 1, 5-7.

50 张骐 等, 中国司法先例与案例指导制度研究 < Study on Chinese Judicial Precedents and the System of Case Guiding > (2016, Peking University Press) 7 .

51 E.g. 江苏仪建建设集团有限公司 v 阳光财产保险股份有限公司青海省分公司, 最高人民法院, (2017) 最高法民终 166 号 (28 June 2017); 白城市红日路桥建设有限 公司 $\mathrm{V}$ 白山市市政建设有限公司, 吉林省高级人民法院, (2018) 吉民终 218 号 (20 June 2018); 七台河嘉晨选煤有限公司 $\mathrm{v}$ 孙风才, 黑龙江省七台河市中级人民 法院, (2018) 黑 09 民终550 号 (17 December 2018).
} 
favourably. On most occasions, the court chose to not respond to such an argument in its judgment. Nevertheless, some dismissal of non-guiding cases came from the court without obvious prompt by the parties. Some of these comments were evidently reasonable without much controversy, such as where the convicted defendants cited a case and its analysis from a law journal as grounds for appealing the conviction. Even though the judgment did not identify the case nor the journal, it stated that the court should apply the law and not the opinions in journal articles, subject to the exception that the court "may" refer to guiding cases published by the Supreme People's Court. ${ }^{52}$ Nevertheless, at times the court have spontaneously pointed out the fact that a case relied by one party is not a guiding case, even if the case was published through official channels such as the Gazette of the Supreme People's Court. ${ }^{53}$ Notably, even the Supreme People's Court itself, in dismissing the relevance of a cited case, would draw attention to the fact that a recent decision by the Supreme People's Court is not a guiding case. ${ }^{54}$ Moreover, the Supreme People's Court explicitly rejected the submission from one party to "refer" to a case in the Gazette of the Supreme People's Court, on the ground that it was not a guiding case, ${ }^{55}$ despite the fact that the case remains well publicized on its own website. ${ }^{56}$

All these cases expose a significant side-effect of the increasing prominence of guiding cases that has rarely been contemplated in the promotion of the idea. In order to avoid overstepping the line between adjudicating and legislating, the judiciary have been careful in saying as little as possible regarding the official and practical status of cases for decades. The permission in the Organic Law that the Supreme People's Court "may" publish guiding cases and the rule that all levels of the court "should" "refer" to guiding cases are major breakthroughs in this regard. Yet the chronic silence over the past decades is now leading to a somewhat inevitable confrontation between the sanctioned use of guiding cases and the practical role played by cases in Chinese law at all levels of the court system. Although the Organic Law and the Detailed Rules

52 钟占伦、钟占风挪用公款二审刑事裁定书, 贵州省黔东南苗族侗族自治州中级 人民法院, (2018) 黔 26 刑终 246 号 (17 December 2018). The wording of “may" (可以) is an intriguing departure from the Supreme People's Court's stipulation of "should” (应当). 上海易程集装罐运输服务有限公司 $\mathrm{v}$ 陕西省蒲城县人民法院，陕西省高级人民 法院赔偿委员会, (2018) 陕委赔监 26 号 (24 December 2018).

54 中国建设银行股份有限公司榆林新建南路支行 $\mathrm{v}$ 榆林聚能物流有限责任公司, 最高人民法院, (2017) 最高法民终 170 号 (17 November 2017). 黄木兴 $\mathrm{v}$ 四川中南明大置业投资有限公司，最高人民法院, (2014) 民申字第 441 号 (4June 2014).

56 “吴国军诉陈晓富、王克祥及德清县中建房地产开发有限公司民间借贷、担保 合同纠纷案” <http://gongbao.court.gov.cn/Details/79f4435dbaf56dbd78e 713f435c320 .html $>$ accessed 1 January 2019. 
authorize, even prescribe, the reference to guiding cases, there has never been any indication that anyone envisaged guiding cases as the only group of cases to be referred to. Indeed, the expectation, if not plan, has always been that with the increasing awareness and capabilities of using guiding cases, the Chinese system will gradually make better use of cases in general. ${ }^{57}$ Although it has never been suggested that China will ever recognize principles such as stare decisis, the notion of establishing "case law" to some extent and in some forms has certainly been a popular topic of academic discussion. ${ }^{58}$

It seems important that the Supreme People's Court among others should take the lead on clarifying this matter of legal principle and practical significance. At least it should be made clear that the Organic Law and rules which require the court to refer to guiding cases do not prohibit the use of other nonguiding cases. Although the status of a guiding case should be afforded due consideration by the court and the parties, the fact that any case is not a guiding case should not be seen as the reason to dismiss or ignore it. Chinese law would need more than 106, 200, or 500 cases in the coming decades. For the court in general, keeping a low-profile on the issue of using cases might have worked in the past, but it is likely to be more and more difficult now that parties start questioning every case not on the hallowed list of guiding cases.

At the same time, this crucial period in the development of Chinese law also poses considerable challenges to scholarly studies of the changing system. For decades, cases were not an important part in the examination of Chinese law. There are two main explanations for this. Doctrinally, as mentioned above, China follows the Civil Law tradition and does not officially recognize the role of case law. More practically, cases are decided by more than three thousand courts all over the country and nobody could have kept track of even the most important ones without established mechanisms such as indexing or case reporting. ${ }^{59}$ Although the court judgment in most cases would be a public document theoretically open to everybody, very few would have the knowledge, time and resources to access these. Only a very small number of cases get selected into more widely available publications such as the Gazette of the Supreme People's Court or other case compilations, occasionally discussed in academic discourse.

57 汤文平, “中国特色判例制度之系统发动” (2018/6) The Jurist 49, 62.

58 张骐, “判例法的比较研究” (2002/4) Journal of Comparative Law 79, 91; 何然, “司法判 例制度论要” (2014/1) Peking University Law Journal 234, 256.

59 An established system of law reports is certainly seen as a systemic strength of a Common Law jurisdiction, which China did not have and would have difficulty in trying to emulate, see 张骐, “判例法的比较研究” (2002/4) Journal of Comparative Law 79, 82. 
Nevertheless, the practical situation of a scarcity of cases was reversed within a very short period of time, almost simultaneous to the development of the system of guiding cases, when the Supreme People's Court started in 2013 to require all decisions by all courts in China to be uploaded onto its online database, China Judgements Online. ${ }^{60}$ Subject to exceptions such as cases involving national secrets, criminal proceedings against minors, divorce proceedings or other cases considered inappropriate for online publication, ${ }^{61}$ the court "should" publish any decision within seven working days of it taking legal effect. ${ }^{62}$ Even for any case deemed unsuitable for online publication, the court should publish the case number, the court of the judgment, the date of the judgment and the reasons for not publishing the judgment, unless where this information would compromise national secrets. ${ }^{63}$

Perhaps not every court adheres to what they "should" or must do all the time. For example, the Supreme People's Court reported 19.77 million decisions by all courts in 2016, ${ }^{64}$ but only 12.25 million documents dated to 2016 have been included in the database. There are also duplications of the same document and multiple documents in relation to the same proceedings. Still the reality is that more than 15 million cases have been published each year in 2017 and 2018. At the latest number count of over 60 million judgments at the end of 2018, this may indeed be the largest database of judicial decisions in the world, as claimed by the Supreme People's Court, ${ }^{65}$ not to mention the fact that it grows by about 50,000 cases every working day. Even though the database is equipped with standard functions such as full-text search, filtering and sorting, the scale is simply overwhelming for any traditional approach in identifying and examining relevant cases. There has been no suggestion as to how the examination of even a specific area of Chinese law could approach this behemoth task in a methodological and rigorous way.

While the puzzle of scholarly examination remains to be solved, the court in China are certainly making use of the massive wealth of judicial wisdom now easily accessible from any computer. The same database now also provides more and more instances of how cases are actually used in Chinese

\footnotetext{
6o <http://wenshu.court.gov.cn/> accessed 1 January 2019.

61 Supreme People's Court, “最高人民法院关于人民法院在互联网公布裁判文书的规 定”(法释 [2016] 19号), Article 4.

62 Ibid., Article 7.

63 Ibid., Article 6.

64 周强, “最高人民法院工作报告”（12 March 2017）<http://www.court.gov.cn/zixun -xiangqing-37852.html> accessed 1 January 2019.

65 Supreme People's Court, “最高法院召开司法公开工作座谈会” (28 February 2018) $<$ http://www.court.gov.cn/zixun-xiangqing-82532.html > accessed 1 January 2019.
} 
law even without any official recognition. In a recent case from Beijing, for example, the claimant and defendants were members of a peer-to-peer loan bidding association (标会 biao hui), which in essence collects agreed contribution from each member to be lent to the highest bidder for the sum among the members. When some disputes in relation to repayment of the sum ended up in litigation, the first instance court comprising a deputy judge sitting on her own, took this as ordinary private lending and worked out the arrangement of capital repayment and interest accordingly. ${ }^{66}$ On appeal, however, the Third Intermediate People's Court of Beijing were more hesitant over the nature of the alleged debt in relation to the participation of such peer-to-peer association. The court explicitly stated that, after examining judgments of relevant cases published on China Judgements Online in recent years, it came to the view that such activities were common to the coastal regions in the Southeast, with most of the decided cases coming from Fujian Province there. And from these judgments, the court concluded that the courts in Fujian Province mostly refused to accept the activities of these peer-to-peer associations as lawful private lending, due to non-compliance with finance regulations and the commonplace risks both financially and legally. The claim and counterclaim were then dismissed by the appeal court. ${ }^{67}$ The dissatisfied claimant later applied for a retrial in the High People's Court of Beijing, arguing that the appeal court relied on non-guiding cases from Fujian Province, while the case only concerned parties currently resident in Beijing (despite all of them being from Fujian originally). Disappointingly perhaps for interested observers, the High People's Court did not venture to answer this highly enticing criticism and simply dismissed the application for a retrial within one succinct paragraph. ${ }^{68}$

Cases such as these offer fascinating insight into the realm of Chinese law largely impervious to scholarly examination until now. There have always been observations and comments on how important cases are in the practice of Chinese law, not only from academics but sometimes also from the court. Yet there is little understanding of how cases are actually discovered or considered by the court. In the Beijing lending association case, for instance, both sides were represented by the same attorneys throughout the three hearings. Did either of the attorneys cite those decisive cases to the appellate court? And what factors would influence the court on deciding whether to rely on or disregard a decision? Without any indication that the law in Beijing is any different

66 傅清月 $\mathrm{v}$ 黄心庆，北京市朝阳区人民法院,(2018) 京 0105 民初 7227 号 (22 February 2018).

67 黄心庆 $\mathrm{v}$ 傅清月, 北京市第三中级人民法院, (2018)京03民终7142 号 (25 June 2018).

68 傅清月 $\mathrm{v}$ 黄心庆，北京市高级人民法院, (2018)京民申 2212 号 (21 December 2018). 
from that of any other province of China, would cases from, say Fujian, be less persuasive than cases from Beijing for a court in Beijing? The questions would quickly queue up for only one case. Yet there may be dozens more waiting to be examined in the search for a better and more realistic understanding of Chinese law.

In his seminal work on the topic of case law in 2002, Zhang Qi envisaged a number of difficulties in constructing a system of case law with Chinese characteristics. ${ }^{69}$ There have certainly been changes in some aspects of these difficulties, for example the limited length of judgments in general, while others may well remain, such as the considerable diversity of China geographically and structurally. Both the system of guiding cases and the China Judgements Online database are having profound impacts on how cases are studied and used in Chinese law. Although China is still as far away from adopting any notion of Common Law as it has ever been, it may be suggested that the emerging system of case law is tentatively making progress, often away from the limelight of guiding cases. And it is up to judges, practitioners and scholars with their interest in Chinese law to examine, explain and extrapolate these important developments of the law at a challenging and exciting time for the country and its legal system.

China International Commercial Court and the Belt and Road Initiative

At the same time, the current approach of the Chinese court in using cases without making clear as to the basic principles and perimeters of such usage is arguably an important aspect of the "Chinese characteristics" of the socialist rule of law that the system commits to pursue. Such a theme will be largely familiar to political and other social scientists who study China, where pragmatism is often seen as the foremost feature of "Chinese characteristics", especially among scholars from outside of China. ${ }^{70}$ Debates such as whether the "socialism with Chinese characteristics" is a new socialism or a new capitalism have long become clichés, ${ }^{71}$ with China freely adopting values and policies from both camps that suit its need. Of course, neither the Communism Party

69 张骐, “判例法的比较研究” (2002/4) Journal of Comparative Law 79, 93-4.

70 李荷英 秦益成, “国外学者论中国特色社会主义与中国模式述评” (2010/2) Management and Review of Social Science 87, 92.

71 郑杭生, “改革开放三十年社会发展理论和社会转型理论” (2009/2) Social Sciences in China 10, 16. 
nor the Chinese government has ever endorsed any suggestion that Mainland China would be capitalistic to any extent. In this sense, law is no different to other crucial areas of governance in China. It is likely that no Chinese court will ever endorse Common Law as part of the principle or practice of Chinese law. Nevertheless, the official stance that China is not a Common Law country will not prevent the court from creating some de facto system of case law that will be far more powerful than that seen in other Civil Law jurisdictions. In this regard, the Belt and Road Initiative, which dominates many aspects of China's current international and domestic agenda, may inject added incentives for Chinese law to become more Common Law or case law compatible.

In June 2018, the Supreme People's Court announced the establishment of China International Commercial Court (CICC), ${ }^{72}$ colloquially dubbed as the "Belt and Road Court". It may be noted that translation difficulty is again mildly problematic in this context, in that the English word "court" is used for two Chinese words of distinct meaning, namely fa yuan (法院) and fa ting (法庭). Fayuan denotes the collective structure of a court, such as the Supreme People's Court or the High People's Court of any province. Fa ting or simply ting as an abbreviation is a division or branch within a court normally specializing in one subject such as criminal law or civil law, or more specifically the actual venue where a court hearing takes place. The CICC is a fa ting, i.e. branch, within the Supreme People's Court and hence not a separate institution. As things stand, the Supreme People's Court has 19 other divisions or branches known as fa ting or ting, variedly translated into English as "courts" or "tribunals". ${ }^{73}$ The CICC in turn has two branches, with the First International Commercial Court based in Shenzhen in the south of country and the Second International Commercial Court based in Xi'an in the northwest. This geographic separation is intended to naturally direct cases in relation to the Maritime Silk Road (the sea-based "Road") towards Shenzhen and cases along the Silk Road Economic Belt (the land-based "Belt") to Xi'an. ${ }^{74}$

72 Supreme People's Court, “最高人民法院关于设立国际商事法庭若干问题的规定” (法释 [2018] 11 号) “Provisions of the Supreme People's Court on Several Issues Concerning the Establishment of the International Commercial Courts", translation available on Stanford Law School China Guiding Cases Project <https://cgc.law.stanford.edu/ belt-and-road/b-and-r-texts/20180701-provisions-re-intl-commercial-courts/> accessed 1 January 2019.

73 Supreme People's Court, "Organization Chart" < http://english.court.gov.cn/organization .html $>$ accessed 1 January 2019 .

74 For a more detailed account of the CICC, see Siyi Lin, "China's International Commercial Court under the Belt and Road Initiative" (2018) International Company and Commercial Law Review 664. 
The CICC specializes in foreign-related civil, commercial and maritime disputes, similar to the pre-existent Civil Adjudication Tribunal No. 4 within the Supreme People's Court. Any case must be foreign-related (including Hong Kong, Macau or Taiwan) for it to be considered by the CICC, while the main threshold is where the monetary amount in dispute exceeds 300 million RMB. Unlike the Civil Adjudication Tribunal No. 4 and indeed almost all other divisions of the Supreme People's Court, however, the cicc only deals with first instance cases directly submitted to its jurisdiction. More importantly, as the CICC is part of the Supreme People's Court, its first instance decision is final, takes legal effect immediately and not subject to any appeal. ${ }^{75}$ In theory, nothing in the law seems to prevent a possible application to the Supreme People's Court asking for a retrial after the CICC decision has already taken legal effect. In practice, the Supreme People's Court almost never hear cases at first instance nowadays, so it is largely unknown how the retrial application against a non-appealed first instance decision would unfold, if this is ever attempted by any party. In December 2018, the CICC announced on its website that it was already in the process of trying several cases involving foreign companies from Japan, Thailand, the Virgin Islands and so on. Under the current framework of unappealable first instance decisions, it would be highly interesting to monitor how the CICC deal with any case cited to it, as well as the weight it affords to its own decisions in future litigation as time goes on. Indeed, the CICC has already been publishing a number of "typical cases" and "model cases", mainly foreign-related decisions of various Chinese courts from previous years, in both Chinese and English on its official website. ${ }^{76} \mathrm{It}$ is extremely unlikely that the CICC would simply dismiss any relevant case on the grounds that it is not a guiding case and China is not a country of case law. As the highest court in the country, it is almost certain that the CICC will never be bound by any decision anywhere. But this should come as no surprise even for some Common Law jurisdictions. The House of Lords in the UK, for example, famously declared that it would depart from its own decisions when "it appears right to do so".77

And despite the lack of any official acknowledgement of even any intention to engage with the Common Law tradition in the operation of the CICC, there are interesting signs of the awareness of the connection between the Common Law and courts for international commercial disputes. For example, official publications from the court system specifically compare the CICC

\footnotetext{
75 Organic Law of the People's Courts of the People's Republic of China, Article 11.

76 China International Commercial Court, "Typical Cases" <http://cicc.court.gov.cn/html /1/219/199/204/index.html> accessed 1 January 2019.

77 Practice Statement [1966] 3 All ER 77 .
} 
to the Singapore International Commercial Court, the Abu Dhabi Global Market Courts (United Arab Emirates) and the Astana International Financial Centre Court (Kazakhstan). ${ }^{78}$ Meanwhile, Chinese academic discussions have examined the Common Law strength of Singapore in establishing the International Commercial Court, ${ }^{79}$ the adoption of Common Law rules by the Abu Dhabi Global Market Courts, ${ }^{80}$ and the implementation of Common Law at Astana International Financial Centre Court. ${ }^{81}$ It is evident that China is well aware of the dominance of the Common Law tradition and the English language in the context of international commercial courts and the difficulty that China will face if it chooses to ignore them. ${ }^{82}$

On the usage of English in court proceedings, the CICC's rule allowing evidences to be submitted in English without a Chinese translation, if consented to by the parties, is seen as a major breakthrough, even though it theoretically contravenes the Civil Procedure Law of the People's Republic of China. ${ }^{83}$ There is no indication that such a technicality would be a problem for the CICC or the Supreme People's Court. Still, the influence or acceptance of some sort of case law, would be a much more significant breakthrough if it ever happens at the cicc. Yet this would probably take a far less conspicuous form than any express provisions from the Supreme People's Court. It is certainly something worth keeping an eye on.

As China's influence grow on the modern world, Chinese law understandably becomes an important topic for many in China and abroad, whether it is seen as an important part of the continuing progress or a major reason to continue the criticism of the Chinese government and the Communism Party. This article sets out to explain some of the mismatch between the wording and their

78 “国际商事法庭 一个新型的国际商事纠纷解决机构” <http://cicc.court.gov.cn/ $\mathrm{html} / 1 / 218 / 149 / 156 / 828 . h t m l>$ accessed 1 January 2019.

79 初北平, “一带一路多元争端解决中心构建的当下与未来” (2017/6) China Legal Science 72, 89.

80 丁风玲, “一带一路建设中创设中国国际商事法庭的理论探索” (2018/5) Journal of Nanjing University $67,68$.

81 沈伟, “国际商事法庭的趋势逻辑和功能” (2018/5) Chinese Review of International Law 102, 108.

82 蔡伟, “国际商事法庭制度比较规则冲突与构建路径” (2018/5) Global Law Review $175,176$.

83 Siyi Lin, "China's International Commercial Court under the Belt and Road Initiative" (2018) International Company and Commercial Law Review 664, 667. 
meanings in English and Chinese, which could have contributed towards some of the misunderstanding among the divergent views on issues such as the rule of law in China. Chinese law has a lot that need to be improved upon. Yet injudicious analyses by categorizing every law-related issue as a matter for the rule of law or simplistic labelling such as "rule by law", which is not understood in Chinese, would only serve to undermine any legitimate or constructive criticism of the current flaws of Chinese law.

In the meantime, major changes are taking place around some of the fundamental mechanics of Chinese law, sometimes away from the attention from the outside. The system of guiding cases from the Supreme People's Court makes notable differences to the formal role played by cases in the Chinese system, especially lately after its succinct recognition, but not full elaboration, in the Organic Law of the People's Court. Yet the small number of guiding cases are only the tip of a much larger iceberg of the much wider use of cases in China. The establishment of the world's largest judicial decisions database offers a challenging and invaluable opportunity in understanding the under-examined principles and practice of case use in thousands of courts.

And although China will probably never become a Common Law jurisdiction, its pragmatic adoption of many opposing values in the name of "Chinese characteristics" would leave the avenue open to the possibility of a new system of case law. Where the system of guiding cases has provided an example structure, the China International Commercial Court under the Belt and Road Initiative could well be the stage for cases to play a far more prominent role in Chinese law. These are arguably the most exciting perspectives of ongoing changes in Chinese law that warrant further observation and more detailed academic examination.

\section{Acknowledgements}

The author would like to thank Professors Kong Qingjiang and Du Ming for organizing the "China's Belt and Road Initiative" Conference in Beijing, where this paper was first presented. The author is also grateful to Professors Zhang Qi, Gao Wei, Jiang Shuo and Li Honghai (all of Peking University Law School) for sharing their invaluable insights on the topic. All mistakes remain the responsibility of the author. 